\title{
Issues of Implementing Electronic Supply Chain Management (E-SCM) In Enterprise
}

\author{
Trinh Le Tan ${ }^{1}$, Dao Thi Dai Trang ${ }^{2}$ \\ ${ }^{1}$ International School, Duy Tan University, Da Nang, Vietnam \\ ${ }^{2}$ Department of Account, Duy Tan University, Da Nang, Vietnam
}

Email address:

Letandtu@gmail.com (T. L. Tan), Daitrangdtu@gmail.com (D. T. D. Trang)

To cite this article:

Trinh Le Tan, Dao Thi Dai Trang. Issues of Implementing Electronic Supply Chain Management (E-SCM) In Enterprise. European Business \& Management. Vol. 3, No. 5, 2017, pp. 86-94. doi: 10.11648/j.ebm.20170305.13

Received: September 21, 2017; Accepted: October 26, 2017; Published: November 20, 2017

\begin{abstract}
The integrated supply chain management with internet and technology brings new innovation management changes in enterprise. It called electronic supply chain management (E-SCM), to be able to reach the maximum result, the implementation of E-SCM need the ability to create, acquire, capture store, maintain and disseminate the organization's knowledge. This paper is literatures study that discussed about the issues related of benefits and constraints on E-SCM implementation in enterprise. Enterprise that implement E-SCM will have a competitive advantages which can be affecting the increase in performance of enterprise also be more sensitive to market environment changes rather than the competitor. This paper findings the success of E-SCM implemented in enterprise need support from knowledge management (KM).
\end{abstract}

Keywords: Electronic Supply Chain Management, Knowledge Management, Effectiveness, Efficiency, Customer Loyalty, Market Development

\section{Introduction}

The fact that B2B exchanges have been significantly affected by the transformation in sharing information processes, sizes of the companies from giant industrial to small start-ups, whom are conducting Internet based B2B exchanges. It is undeniable that business managers were thrilled by the prospect of its efficiency, effectiveness and innovation, which they believed would overcome barriers in time and geography and improve inter-organizational relation. IT is considered to be of significant strategic importance to most companies [1]. IT becomes a significant factor which create a close relationship between buyers and supplier relationships that will improve the collaboration process. According to [12] ICT allows cost reduction and improvements in product development and quality service in enterprise, resulting in gaining competitive advantage.

In order to develop the supply chain and utilize the IT and internet be known as an electronic supply chain. The electronic supply chain is a process involving enterprise and partners that integrated with a potential of the new technological solutions that allow the sharing of processes, objectives and information that relevant for the entire chain. ICT provides powerful tools that allow organizations to improve supply chain performance significantly, through enhanced process efficiency and integration [8] [15]. In order to find a better competitive advantage and survive in the market with daily increasing changes, all organizations are in need of a dynamic network based upon cooperation in supply chain management.

Internet enables supply chain to create, storage, dissemination and application of organizational knowledge. This third type of impact of the Internet on SCM is called knowledge management [23]. According to [8] KM refers to the set of processes or practice of developing in an organization the ability to create, acquire, capture store, maintain and disseminate the organization's knowledge. To be able to organize the implementation of supply chain, organization needs to be sure the managerial system can maximize the implementation of supply chain. Internet and IT allow efficient inter-organizational information flows, facilitating supply chain management [21]. Electronic supply chain management system can improve supply chain management by allowing effective communication between companies in the supply chain as well as providing easy 
access to information generated. Furthermore, reducing the problem of information overload is considered to be another advantage of e-supply chain [18]. [22] analyzed the role of information sharing and collaborative behavior indicated a positive impact of trust, commitment, reciprocity, commitment and power on both; though supply chain performance is shown to be influenced more by collaboration than information sharing.

In a supply chain, products or services move from the upstream suppliers, through some intermediate links, to the downstream sellers, and ultimately to the end users. Only cooperation can help them to realize the whole value of supply chain. So the essence of supply chain is cooperation, then cooperation and cooperative relationship is not separated. The relationship among enterprises have direct link to the efficiency and benefit of supply chain. More stable the relation more steadies and more efficient the supply chain is [12]. E-collaboration refers to integrating and sharing data, through the internet or extranets. Upstream and downstream value chain process are integrated through cooperation and sharing information, allowing various parties in the supply chain to cooperate with each other in the development and design of products [15].

The main factors that contributed to the transition from SCM to E-SCM are a response to the business requests set from the new needs of the organizations: [19]

The need for additional reduction in the costs as well as improvements in the processes through the expansion of the tools for modern management in the organizations from the supplier channels to the customer channels

The introduction of computerization and digitalization of the internal functions of the organizations with new technique, tools, and management methods.

The need for efficiency and agility of the organizations in order that they can respond to the higher demands of the customers whose growing demands and bargaining power continually increases.

The effort to optimize the organization by having lower inventory levels both in manufacture and distribution by, in parallel, offering supreme quality and service.

The deserting of vertical integration and functional oriented organizations.

The tendency for outsourcing of some operational functions that are not the core of the business to other organizations specialized in that field.

The explosive expansion of global commerce and the opening of new markets that only few years ago were closed.

Finally, the e-business technologies and the internet have enabled organizations of all sizes to have a network and be closely connected, conquer with their partners and compete for market share.

The reason behind this study are to understand the issues related to the electronic supply chain management system in enterprise, to understand what factor that need to be added in successfully implementing electronic supply chain management and describe the role of electronic supply chain management system in enterprise.

\section{Literature Review}

\subsection{Supply Chain Management}

According to the Global Supply Chain Forum, SCM defined as: "The integration of key business processes from end user through original suppliers that provides products, services, and information that add value for customers and other stakeholders." [20] Supply Chain Management (SCM), also known as supply chain integration or supply chain optimization, is the process of optimizing a enterprise's internal practices in interacting with suppliers and customers in order to bring products to market more efficiently [9]

\subsection{Information Technology (IT) and Internet}

According [4] information technology (IT) allows a greater amount of data to be distributed with increased accuracy and frequency along the supply chains and for their activities to be synchronized. As a result, the firms in supply chain are able to efficiently coordinate their business decisions and activities and become integrated.

Internet connection and communication functions operated by the enterprises could result in more efficient information exchange among the enterprises. The operational process would be more successful and enterprises would further reduce the stocks and increase the inventory turnover rate that will boost organizational performance [3]

\subsection{E-Supply Chain Management}

The E-SCM is a concept that can be described as a network of independent partners who are not only distributers of certain products and services in the supply chain, but also stimulate the demand and lead the synchronization of capabilities and resources in the whole supply chain in order that they provide levels of operational efficiency and leadership on the market [10]

E-SCM is a combination between the internet, the supply chain management and the true balance between them [10]

E-SCM is a new dimension derived from the former SCM concept and developed as a result of the evolution of the information technologies as well as reengineering of the organizations' business processes towards partners cooperation enabled by the Internet. [10]

Electronic supply chain management is the internet impact on the integrity of the original business processes from enduser to the main supplier of products, services and provides information to customers and other stakeholders and creates value [24]

Figure 1 explain that [5] proposed that customer relationship management, customer service management, demand management, e-fulfillment, e-procurement, manufacturing flow management, product development and commercialization, and reverse logistics are the part that related to the process of the integration of internet and business process. [17] added some topics that are related with SCM enablers, such as supply chain relationships, planning and optimization tools and information flows. 


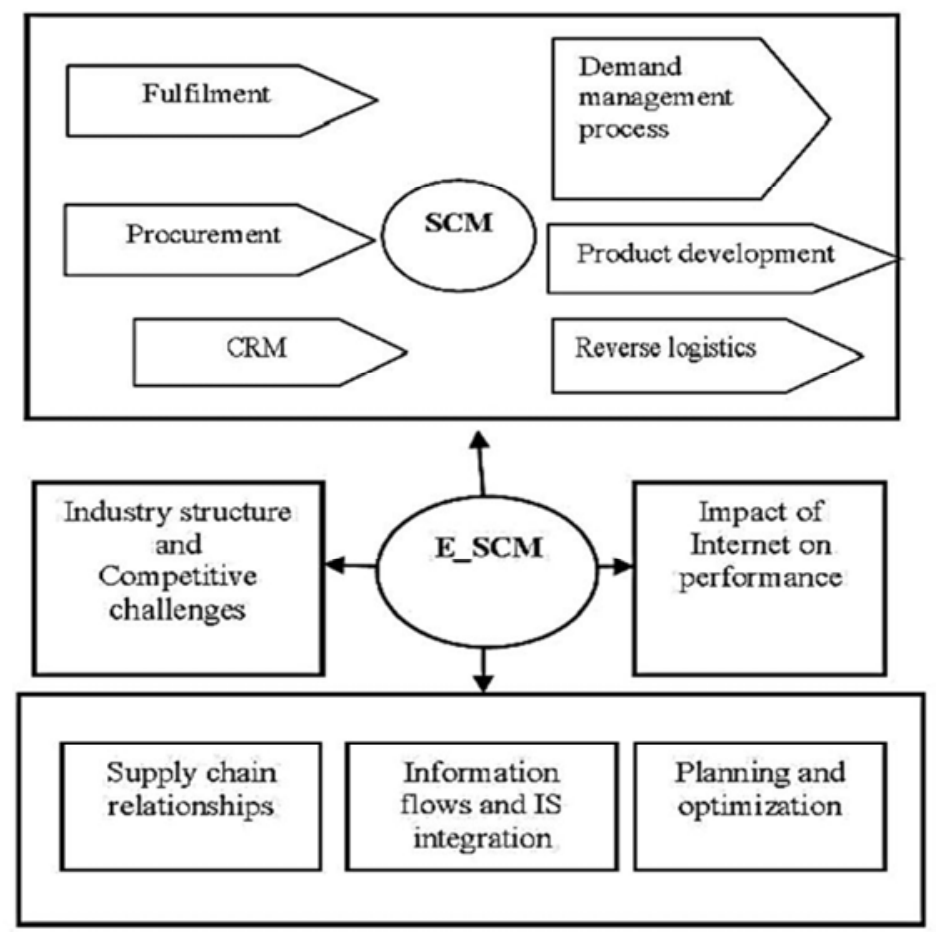

Figure 1. A framework for E-SCM, based on [17].

They also added two topics: industry structure and competitive challenges, and impact on performance. According to them by implementing internet in supply chain management will be affected to some management process in enterprise:

The customer relationship management process

The customer relationship management (CRM) is about developing and maintaining the relation with the customer. The impact of the internet in supply chain related to CRM can be distinguished into two different types of impacts. First is the internal effect. Through the internet either the customer or all business units can get the same information which enables them to negotiate. Second is the downstream effect. The downstream effect refers to the impact of the Internet on the relationships with customers which allows enterprise to provide new services to customers, increasing the companies' products and services offerings then the important is allow enterprise to collect data as users navigate through web sites.

The demand management process

The demand management process includes forecasting demand and synchronizing it with distribution, production and procurement. The impact of the internet in this process affects its upstream and downstream links. The better forecasting will reduce the order process costs and the stock levels. Other than that, electronic supply chain management not only sharing the information but also the knowledge aspect. It enables partner access data analysis and modeling to jointly make a better planning and decision making.

The e-fulfillment process

This process is about the integration of the manufacturing, logistics and marketing functions to ensure customer satisfaction and reduce total cost before, during and after the order fulfillment. The impact of the Internet on the order fulfillment process has two main aspects. First is related with the e-commerce that consists on fulfilling customer order through the internet which increases the efficiency. Second aspect is related to the use of the Internet to improve the efficiency of the order fulfillment process which actually requires the access and manipulation of a large amount of data from customer orders to inventory levels.

The e-procurement process

The e-procurement process supports the procurement and sourcing activities via Internet technologies and enables an efficient negotiation between buyers and suppliers. Several firms have implemented e-procurement solutions not only to reduce costs but also sharing information since this eprocurement process involves retrieving, sharing and storing a large amount of data and information.

The product development and commercialization process

It distinguished into three types of effects: internal, downstream and upstream effects. In internal the Internet enables the collaboration of different functional units in the new product development process. While for the downstream affect, internet helps enterprise to study the target market faster with the cheaper way. And, the upstream effect enables suppliers involved in the process as early as possible in order to reduce costs and time.

The reverse logistics and returns process

It is undeniable that the effective return management became the most attractive weapon to stay in competitive. Managing returns involves managing different types of data such as the reasons for return, conditions of the product, point of return, instructions to customers, etc. The major impact of the Internet on this process consists on providing 
better information and knowledge to all members of the supply chain involved in this process.

According to [14] E-SCM as the management in all the processes in the entire supply chain, such as planning and forecasting, procurement, inventory, production, logistics, sales and information and other resources and customer satisfaction, which is achieved by the means of e-commerce of information technology. They also identified the core features of an E-SCM as:

Strategy of cooperation among members

Intelligent of Information Management

The agility and flexibility of business Integration of the network organization

The most import according to [7], the objectives of E-SCM are:

Providing information availability and visibility

Enabling single point of contact of data

Allowing decisions based on total supply chain information

Enabling collaboration with supply chain partners

\subsection{Knowledge Management}

Knowledge management is a discipline that promotes an integrated approach to identifying, capturing, evaluating, retrieving, and sharing all of an enterprise's information assets. These assets may include databases, documents, policies, procedures, and previously un-captured expertise and experience in individual workers." (Duhon, 1998). The definition of knowledge management from APQC (American Productivity \& Quality Center) is a systematic process that enables information and knowledge to grow, flow, and create value. The KM discipline is about connecting people to the information and expertise they need to achieve business results.

\subsection{Research Findings About E-SCM in Enterprise}

The following findings are about the competitive advantages from implement E-SCM for enterprise.

Table 1. Research Findings.

\begin{tabular}{|c|c|c|}
\hline No & Authors (years) & Significant Finding \\
\hline 1 & Khan. S. A, Liang. Y (2014) & $\begin{array}{l}\text { For SMEs operations E-SCM could be a potential feature to improve on the materials flow and information flow } \\
\text { between supplier and customer. The contribution of supply chain management to firm performance be affected by } \\
\text { market orientation and supply chain orientation. }\end{array}$ \\
\hline 2 & $\begin{array}{l}\text { Ivanovska, L. P and } \\
\text { Kaleshovka, N. (2013) }\end{array}$ & $\begin{array}{l}\text { Electronic supply chain management brings elements that contribute to improved and integrated supply chain } \\
\text { relationships which enabled by technology solutions that allow electronic connection between the partners and their } \\
\text { applications and systems. The Internet in fact enhances E-SCM by making real time information available and } \\
\text { enabling collaboration between the partners }\end{array}$ \\
\hline 3 & Ooi et al., (2009) & $\begin{array}{l}\text { SMEs need to effectively share information in order to implement e-business successfully in their supply chain. In } \\
\text { other words, SMEs that are willing to share essential supply chain information with their trading partners are more } \\
\text { likely to adopt e-business }\end{array}$ \\
\hline 4 & $\begin{array}{l}\text { Chengzhi, J., Zhaohan, S., } \\
\text { (2009) }\end{array}$ & $\begin{array}{l}\text { Having an effective supply chain management represents a vital element in creating a competitive advantage, as it } \\
\text { directly influences coming forward to the changes in the demand effectively and efficiently }\end{array}$ \\
\hline 5 & C. Y. Chen et al., (2006) & $\begin{array}{l}\text { The enterprises' reinforcement of e-Supply chain capability could improve organizational performance; when the } \\
\text { competitive advantages were increased, there would be better organizational performance }\end{array}$ \\
\hline 6 & Hajar Fatorachian. (2012) & $\begin{array}{l}\text { E-SCM system can improve SCM by Allowing effective communication between companies in the supply chain as } \\
\text { well as providing easy access to information generated }\end{array}$ \\
\hline 7 & $\begin{array}{l}\text { Atiq W. Siddiqui and Syed } \\
\text { Arshad Raza. (2015) }\end{array}$ & $\begin{array}{l}\text { An increasing attention, e-Supply Chain Modeling/Design/Implementation showed the greatest increase followed } \\
\text { by Performance Measurement, Evaluation and Impact and Supply Chain Integration and Collaboration }\end{array}$ \\
\hline 8 & $\begin{array}{l}\text { Navid Nikakhtar* and Yang } \\
\text { Jianzheng. (2012) }\end{array}$ & $\begin{array}{l}\text { The competitive advantage by the use of electronic supply chain as a basic and fundamental factor in fixed and } \\
\text { maintenance of next step and make better situation than other competitors in market and industry. The electronic } \\
\text { supply chain management that efficiency and applications may assist the organization for obtaining a high rate of } \\
\text { competitive advantage against competitors in market }\end{array}$ \\
\hline 9 & Dehning et al., (2007). & $\begin{array}{l}\text { The potential performance improvement with e-supply chains (e-SCs) that are directly observed as cost reductions, } \\
\text { increased responsiveness, and better financial performance }\end{array}$ \\
\hline 10 & $\begin{array}{l}\text { Ghasemi, A., Shirmohamadi, } \\
\text { M., Taimouri, A.,(2015) }\end{array}$ & $\begin{array}{l}\text { The use of electronic supply chain management in companies and factories will reduce administrative costs; } \\
\text { improve process efficiency, greater integration, increased agility and flexibility of the organization and lower effect } \\
\text { occurs in terms of supply chain, reduce inventory levels, faster access to information as well as improve } \\
\text { communications and customer service. All of these advantages reduce operating costs, increase productivity, } \\
\text { increase revenue and so on, which indicates improvement in the economic performance of the enterprise or } \\
\text { organization }\end{array}$ \\
\hline 11 & $\begin{array}{l}\text { Maymand, Dr. Mohammad } \\
\text { M and Mohebi, N., (2016) }\end{array}$ & $\begin{array}{l}\text { Implementing electronic supply chain can help making-loyalty among customers and in this case improving } \\
\text { satisfaction level, trust and loyalty of customer on organization or enterprise. The improving satisfaction level is } \\
\text { more important in making customer's loyalty }\end{array}$ \\
\hline 12 & $\begin{array}{l}\text { Valverde, R., and Saadé, R. } \\
\text { G. (2015) }\end{array}$ & $\begin{array}{l}\text { E-SCM has positive impact because conducting better communication between the firm and it supplier, facilitates } \\
\text { document preparation and provides for better remote access capability. The survey revealed that the use of E-SCM } \\
\text { in the firm will lead to fewer errors thus cost savings }\end{array}$ \\
\hline 13 & $\begin{array}{l}\text { A. Mohammadi, M. Sahrakar } \\
\text { and H. R. Yazdani (2012) }\end{array}$ & $\begin{array}{l}\text { A study that revealed that the improvement in supply chain capabilities through Information Technology (IT) } \\
\text { allows the firm to learn and respond to market changes better and quicker than competitors. }\end{array}$ \\
\hline 14 & Maguire et al., (2007) & $\begin{array}{l}\text { "Spreadsheets and databases as well as intranets" continue to be considered as main applications in creating } \\
\text { competitive advantage in SMEs. Innovative use of the internet allows SMEs to take advantage of market opportunities }\end{array}$ \\
\hline 15 & Devaraj et al, (2007) & The most important impact of the Internet on supply chain management is likely to share large amounts of \\
\hline
\end{tabular}




\begin{tabular}{|c|c|c|}
\hline No & Authors (years) & Significant Finding \\
\hline 16 & Maguire et al. (2007) & $\begin{array}{l}\text { information in terms of supply chain, in real time, including operations, logistics, and strategic planning. This truth } \\
\text { helps the companies to seem better, have better production planning and also improve their distribution system } \\
\text { Investigated the use of ICT in SMEs by explaining the used of management approaches and e-business in order of } \\
\text { gaining competitive advantage such as, cost reduction and improvements in product development and service } \\
\text { quality. According to them the most effective ways of using ICT in SMEs are "salesforecasting, customer analysis } \\
\text { and pricing". They stated that today's business environment the effective use of IS and IT can provide small firms } \\
\text { with the opportunity to take advantage of ICT }\end{array}$ \\
\hline 17 & Sayadi et al, 2014 & $\begin{array}{l}\text { Sharing knowledge is considered as a competitive advantage for supply chain. The managers found that only } \\
\text { production of a quality product is not enough, in fact, preparation of products with needs of customers and quality } \\
\text { and desired cost has created a new challenge }\end{array}$ \\
\hline 18 & $\begin{array}{l}\text { Shakeriana, H,. Dehnavia, D, } \\
\text { H., Shaterib, F, } 2016\end{array}$ & $\begin{array}{l}\text { Knowledge management }(\mathrm{KM}) \text { is one of the most important competitive resources in each organization so that } \\
\text { many believe that companies who can get knowledge and applies it faster, they will be more successful in } \\
\text { competitive market. Knowledge management is major capability of supply chain management and vital element of } \\
\text { intensive information and multi-cultural organizational environment. }\end{array}$ \\
\hline
\end{tabular}

\section{Methodology}

Data used in this research is secondary data. Secondary data is a time series data from 2000 to 2016 (16 years). Time series data is the data that is collected over time to provide an overview of the development of an activity during a specific period observed. This paper is a literatures study of the previous study and past research from 18 journals.

\section{Discussion}

The implementation of electronic supply chain management can make enterprise more effective because high level of responsiveness like a faster access to communication, information sharing and customer service because in fact the internet enhances E-SCM by making real time information available and enabling collaboration between the partners cause the easy access to information generated, also make a greater integration, improve the management quality of enterprise, reduce inventory increasing agility and flexibility that reduce transaction costs in purchasing, reduce levels of inventory across a supply chain, also facilitates document preparation and provides for better remote access capability which will shorten production planning horizons, and increase potential for optimal distributions, reduce the impact of problems or errors that may occur of supply chain management in the enterprise.

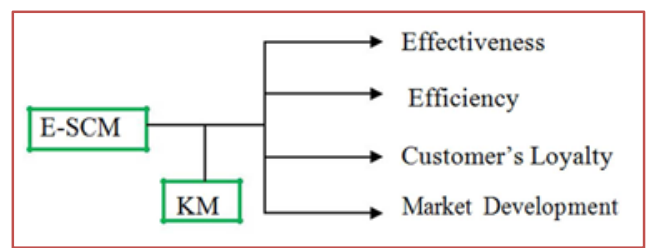

Figure 2. Framework in implementing E-SCM integrate with knowledge management.

Over all we can say by implementing E-SCM enterprise will boost the effectiveness and efficiency by reduce operating costs, increase productivity finally increase revenue which indicates improvement in the economic performance of the enterprise or organization. Based on the previous research, implementation E-SCM in enterprise will have a better performance, a high level of performance will impact the satisfaction and pleasant' customer thus make an enterprise trusted. Implementing electronic supply chain management can making-loyalty among customers. For example, if ordering process of electronic supply system has adequate attractiveness and high efficiency, it causes to reinforce satisfaction, trust and consequently causes to customer's loyalty.

Internet and Information Technology (IT) are considered to be a significant strategic to most enterprise. [2] revealed that the improvement in supply chain capabilities through IT allows the firm to learn and respond to market changes better and quicker than competitors. The common used of the Internet is to extend enterprise from agent to agent, customer to customer, agent to the customer so there is no lack of time and distance and as result would lead to the satisfaction of the customer because of speed, agility and on time control. From above, the enterprise with E-SCM system will have a different scope of market with the not. Cause E-SCM will help enterprise to further develop. The role of E-SCM in management companies have an important role for the survival of the enterprise and allows enterprise to expand network market

Enterprise will get competitive advantages such as customer's loyalty, efficiency and effective also able to do market development only if they have a good knowledge management (KM). To be knowledge management success, there are 7 key factors identified. These factors include: strong relation to business, perspective and mandatory architecture, knowledge leadership, the culture of creating and sharing knowledge, continuous learning, developed technology infrastructure, and systematic organizational knowledge process. According to [27] some criteria for the process of knowledge management in supply chain were define to identification of customers' needs regularly and periodically, evaluation of service and products quality of chain annually, evaluation the effect of changes. [26] defined that the focus of knowledge management on socialization is to remove the barriers of network and develop trade relations between major enterprise and its competitors in chain supply.

As we know that knowledge management has a major role in supply chain management. Knowledge management (KM) is believed as one of the most important competitive 
resources in competitive market. To implement knowledge management in supply chain there are two kind of sides that need to be concern: internal and external. As internalization factor, the initialization and implementation of knowledge phases step such as transfers explicit to implicit knowledge across applications of knowledge management through learning, quick solutions and sharing internal information. While the external factor include structural change of documents, contract documents, structural meetings and formal process. Externalization is more important in knowledge management of supply chain because sharing the informal information among structural meetings and information sharing processes enable to support and collaborative progress in supply chain network. [26] so we believe that enterprise can get effectiveness, efficiency, consumer's loyalty and market development by integrating KM initiatives with E-SCM.

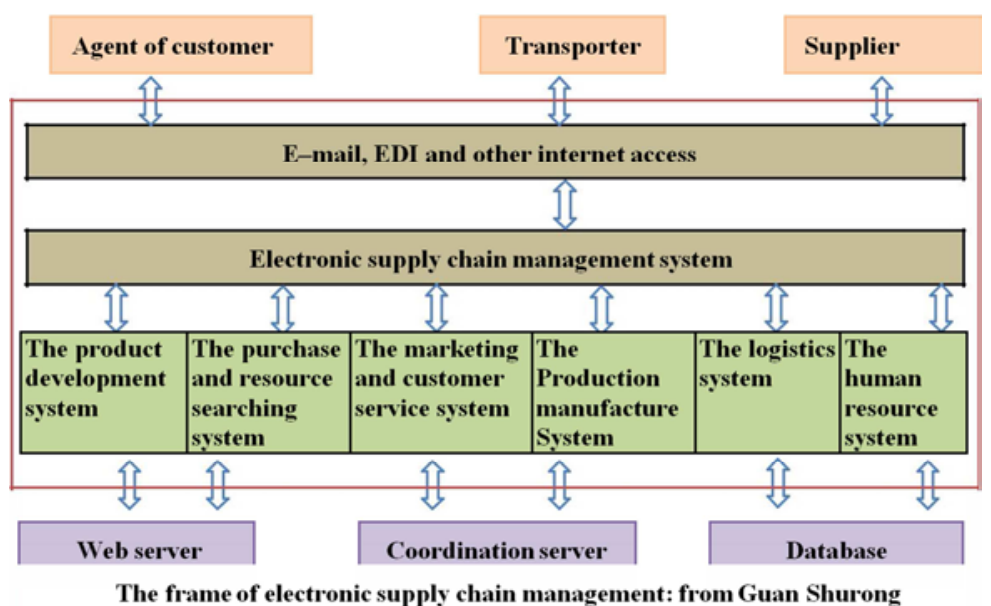

Figure 3. Adoption of E-Supply Chain Management.

From the figure we can see that by adopting electronic supply chain management, the agent of customer, the transporter and the supplier can exchange their information through E-mail, Electronic Data Interchange (EDI) and other access without visiting the partners physically. Then with the electronic supply chain management system make it easier to them in order to access the important data. Electronic supply chain management system also concludes the subsystems giving the advantages by helping them to develop product and to search also purchase sources that can be coordinate through web server. It also helps them monitoring the marketing, customer service and the production manufacture through coordination server.

Lastly, the electronic supply chain management system will be very useful to coordinate the logistics and the human resource system through database even the subsystems are managed by different departments, their also can connect with each other. According to [14] E-SCM puts emphasis on the sharing resources and integration of information systems between the participating entities in the supply chain. They also mentioned that with the use of the information technology, it is possible to collect and analyses various information in the supply chain and with this the business can manage full range of information on the purchase of raw materials, production, distribution, marketing, customer relationship and react fast to business changes in demand and trends.

\subsection{The Implementation of Electronic Supply Chain Management}

The E-SCM implement process includes looking for the trade partners, purchases, goods transportation and track, payments and post-sale services. Follow as:

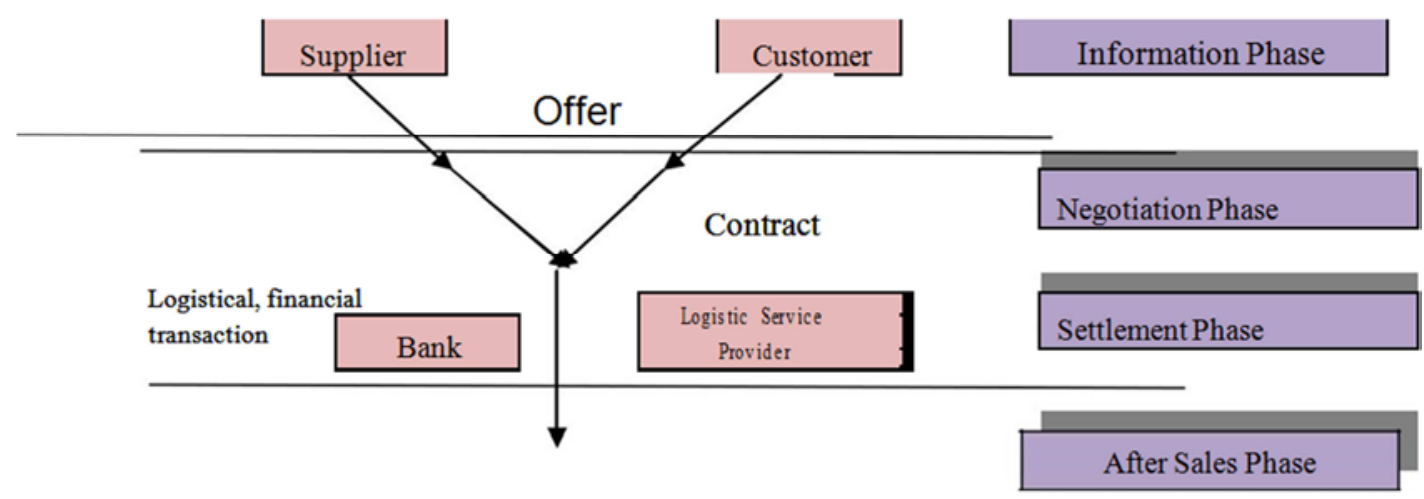

Figure 4. Phases of market transactions: comparison of Schmidan Lindemann, 1998 and. 
The implement of supply chain in international trade as the example explained [4] as the follow:

Looking For the Trade Partners

With the electronic commerce platform, enterprise can provide supply and demand information about the related products and the services to the customers around the world without going abroad which need a extremely high cost or in the other word as international trade so that domestic importers and exporters can find appropriate foreign trade partners.

Electronic Purchases

To simplify the goods distribution, reduce the cost and improve the efficiency performance of the enterprise. Present electronic purchase software may be divided into 3 categories advantages, there are:

Can help the enterprise staffs to carry on the purchase through the computer.

Can helps manager and the buyer to manage the purchase process, analyze transaction information and manage the suppliers.

Can helps the manufacturers and distributors to sell products through the network. It usually includes the electronic catalogue, the electronic transaction order and so on Electronic Transportation and Track

EDI

EDI is being used in booking, handling containers and ships, tracking the cargos, transmitting documents, finance and settlement. With the application of merchandise tracking system on internet, the customers and trade partners can directly get inquire about the information of the cargo' conditions, get the transportation and commercial partners' information

Online Payments

The online payment is e-bank will be established, so the domestic and foreign banks are adjusting their own strategies to meet the increasingly high requests of a bank in the electronic international trade

Electronic Post-sale Services

Internet is used in the post-sale service to collect the information of the customers and the products and store them into the database, also provides the new business increase for the enterprise and promotes customers' satisfaction and loyalty

Transactions Management Network

Electronic business makes the international trade transactions achieve network management paperless. The engaged enterprises can directly handle with the banks, the insurance companies, the taxation departments and the transportation companies to manage the related electronic bills and the electronic documents through internet, which has saved the time and the expense in transaction process. Examples of enterprise that success of implement E-SCM: Dell, Walmart, Lanier Worldwide Inc, Ford Motor Enterprise and UPS Logistics group, Cisco Fujitsu in America, Adaptec, Home Depot, Proflowers. com's cooperation with FedEx, HP etc.

\subsection{Challenges and Benefit E-SCM}

\subsubsection{Benefit}

Easily Communicate and effectively with each other.

Provides easy access to data generated, which can be provide useable information to those that need it.

Information visibility and sharing, because of the easy access between enterprise or with supplier, they can get the visible information and sharing

Real time communication, the facility that provide by internet and information technology could improve communication between enterprise, supplier or agent become faster and in a real time

Order tracking, provide exact information about the order existence

Better real-time forecasting decision

Faster delivery; one of the most valuable advantage from ESCM is the availability of update information, such as an update number of inventory that will improve the distribution of inventory with no need having a warehouse

Improved partner relationships, because of the easy access which can increase the bonding

Understanding of customer needs,

Increased customer satisfaction, related with the previous point, it will boost customer's satisfaction

Faster market adaptation. Enterprise with the internet implementation can comply market movement

Reduced resources, by implementing ESCM enterprise does not need to have their own warehouse, because they could implement a just-in-time method

Cost savings; the ease of E-SCM can decrease enterprise cost in order to get a better performance

Increased profits. by reducing enterprise's resource need, they will reduce the cost which impacted to the increase profit

\subsubsection{Challenges}

One of the major problems that occur relates to problems with integrating is the technology used by the various parties in the supply chain. It is undeniable that one enterprise uses a software system that will not integrate easily with others or in this case supplier technologies. This creates a problem because it requires one of the suppliers to change their system to allow integration. If the supplier has one major customer, this may be not a problem, but the fact that many suppliers have various customers.

A lack of communication and blockage of transaction or goods with customers along the supply chain will make a broken supply chain that cause inefficiencies, reduces speed to market, and ultimately increases costs.

Electronic supply chain collaboration has proved difficult to implement in practice as there has been an over-reliance on technology and a failure to understand what information needs to be shared and, especially, how the business processes need to be changed when new technology is implemented [19] 
To ensure the maximum use the enterprise must spend time and resources on upfront strategy development. Analyzing SCM opportunities and creating a clear E-Supply Chain roadmap and strategy offers the possibility to improve performance and successfully adopted.

Firms with high levels of e-Supply chain capability uncertainly have high levels of competitive advantage. The reason might be in that corporate supply chain strategies would be influenced by contextual factors, such as the type of industry, firm size, a firm's position in the supply chain, supply chain length, and the type of a supply chain (divergent or convergence networks) [3]

According to [7] globalization, technology, e-business barriers and competency based on issues impact the development of e-supply chain in SMEs. In other words, it is important to consider the various natures, the ability to recognize and develop business opportunities when assessing the adoption of ICT and e-business technologies in SMEs (Taylor and Murphy, 2004).

As we explained earlier, in order to against challenges above enterprise need to have a knowledge management while implementing E-SCM.

\section{Conclusion}

Internet and IT influence SCM in enterprise, which give ease for sharing information, real time communication to customer or supplier, enabling to give fast response, et cetera. This advantage impacted to improve customer satisfaction, efficiency and effectiveness and increase the enterprise' chance to do market development. The enterprise must also understand how technology does not automatically generate increase in the productivity, but it requires support from knowledge management. To be success knowledge management enterprise should have strong relation to business, perspective and mandatory architecture, knowledge leadership, the culture of creating and sharing knowledge, continuous learning, developed technology infrastructure, and systematic organizational knowledge process. Not only that in implement E-SCM there are some challenges that need to be faced by enterprise. Limitation of this study are:

Author not yet found the negative impact of knowledge management if it exists

Author can't find other competitive advantages of implement E-SCM within knowledge management

Author can't specifically determine the implementation of knowledge management in E-SCM system will be successful in all type of companies

\section{References}

[1] APQC. (2011). Process Classification Framework: Knowledge, Improvement, and Change Management Definitions and Key Measures. Houston, Texas: APQC.

[2] A. Mohammadi, M. Sahrakar and H. R. Yazdani, 2012. Investigating the effects of information technology on the capabilities and performance of the supply chain of dairy companies in Fars province: A multiple case study African, Journal of Business Management, vol. 6, no. 3, pp. 933-945.

[3] C. Y. Chen et al., 2006. The Impact of E-Supply Chain Capability on Competitive Advantage and Organizational Performance Vol. 4, No. 5, pp. 419-427. Taiwan: International Journal of Electronic Business Management.

[4] Chen, H., Kong, L., 2007, An Analysis on the Implementation of Electronic Supply Chain in International Trade, Volume: 251. Boston: Springer.

[5] Cooper, M. C., Lambert, D. M. and Pagh, J. D. (1997), "Supply chain management: More than a new name for logistics", The International Journal of Logistics Management, Vol. 8 No. 1, pp. 1-13.

[6] Devaraj, S., et al. (2007). "Impact of eBusiness technologies on operational performance: The role of production information integration in the supply chain." Journal of Operations Management 25 (6): 1199-1216.

[7] D. Simchi-Levi, P. Kaminsky and E. Simchi-Levi. 2003 Designing and Managing the Supply Chain: Concepts, Strategies and Case Studies. New York: McGraw-Hill.

[8] E. W. T. Ngai, E. W. C. Chan, Evaluation of knowledge management tools using AHP, Expert Systems with Applications, Elsevier, 29, 2005, pp 889-899.

[9] León-Peña J. R., 2008. E-Business and the Supply Chain Management, Vol.1 No.1. Mexico: Business Intelligence Journal.

[10] Ivanovska, L. P and Kaleshovka, N., 2013. Implementation of e-Supply Chain Management, TEM Journal, Vol. 2 No. 4, pp. 314-322.

[11] Khan, S. A., Liang, Y. and Shahzad, S. 2014. Adoption of Electronic Supply Chain Management and E-Commerce by Small and Medium Enterprises and Their Performance: A Survey of SMEs in Pakistan. American Journal of Industrial and Business Management, 4, 433-441. http://dx.doi.org/10.4236/ajibm.2014.49051.

[12] Maguire, S., Koh, S. C. L. and Magrys, A. (2007). The adoption of e-business and knowledge management in SMEs. Benchmarking: An International Journal, 14 (1), 37-58.

[13] Min, S., Mentzer, J. T,. \& Ladd, R. T., 2007. A market orientation in supply chain management. Vol 35:507-522. USA: Academy of Marketing Science.

[14] H. Hua and P. Cong, 2011. Analysis of E-SCM, in Communication Systems and Information Technology (M. Ma, Ed.). Berlin Heidelber: Springer-Verlag, pp. 867-874.

[15] Koenig, M 2012, What is KM? Knowledge Management Explained, KMWorld, May 4, retrieved july 10, 2017 (http://www.kmworld.com/Articles/Editorial/What-Is.../What-is-KM-Knowledge-Management-Explained82405.aspx).

[16] Valverde, R., and Saadé, R. G. 2015. The Effect of E-Supply Chain Management Systems in the North American Electronic Manufacturing Services Industry. Journal of Theoretical and Applied Electronic Commerce Research Electronic Version VOL 10 / ISSUE 1/79-98. Chile: Universidad de Talca. 
[17] Gime nez, C. and Lourenco, H. R. (2008). E-SCM: internet's impact on supply chain processes. The International Journal of Logistics Management. 19 (3), 309-343.

[18] Leon-Pena, J. R. (2008). E-business and the supply chain management. Business Intelligence Journal, 1 (1), 77-89.

[19] Lidija Pulevska-Ivanovska, Neda Kaleshovska, (2013). Implementation of e-Supply Chain Management, TEM Journal, 2 (4), pp. 314-322.

[20] Maguire, S., Koh, S. C. L. and Magrys, A. (2007). The adoption of e-business and knowledge management in SMEs. Benchmarking: An International Journal, 14 (1), 37-58.

[21] Ooi, K. et al. (2009). Influence of inter organizational relationships on SMEs' e-business adoption. Internet Research, 19 (3), 313-331.

[22] Wu, I.-L., Chuang, C.-H., \& Hsu, C.-H. (2014). Information sharing and collaborative behaviors in enabling supply chain performance: A social exchange perspective. International Journal of Production Economics, 148, 122-132.

[23] Maymand, Dr. Mohammad M and Mohebi, N., 2016. The
Effect of Electronic Supply Chain Management E-SCM on Customers' Loyalty in Consumer Goods. Iran: INTERNATIONAL JOURNAL OF HUMANITIES AND CULTURAL STUDIES pp: 352-364.

[24] Ghasemi, A., Shirmohamadi, M., Taimouri, A., 2015. Assessing the Impact of Electronic Supply Chain Management on the Performance of Small and Medium sized Enterprises using the Sustainable Balanced Scorecard Approach (Case Study of Online Stores and Industrial town of Abasabad). Iran: International Journal of Scientific Management and Development Vol. 3 (12), 670-677.

[25] Sayadi, Sina; Poursheik, Ali, (2014), Knowledge management systems in government agencies, First international conference on accounting, auditing and management.

[26] Shakeriana, H,. Dehnavia, D, H., Shaterib, F,. 2016. A framework for the implementation of knowledge management in supply chain management. Iran: Procedia - Social and Behavioral Sciences 230, pp: $176-183$.

[27] Serna, Edgar. 2015. Maturity model of trans disciplinary knowledge management, International journal of information management, No: 35, pp: 647-654. 